УДК 339. 982 DOI: https://doi.org/10.31617/zt.knute.2020(109)03

ОНИщЕНко Володимир д. е. н., професор, професор кафедри світової економіки

E-mail:ov2016@ukr.net торговельно-економічного університету

ORCID: 0000-0003-0513-705X вул. Kiото, 19, м. Київ, 02156, Україна

\title{
ГЕНЕЗИС СВІТОВОГО ЕКОНОМІЧНОГО ПОРЯДКУ
}

\author{
«Світ у порядку, иче щзось з людьми не так»
} Джсорж Карлін

Визначено, що світовий економічний порядок (СЕП) є системою міжнародних відносин між суб'єктами світової економіки, що структурована легітимними формальними та неформальними правилами. Зазначено, що СЕП сформовано природним шляхом у глобальному просторі економічної та політичної конкуренції. Досліджено, що мету, дерево иілей, структуру відносин в рамках СЕП, визначають краӥни-лідери через систему легітимних глобальних інститутів, заснованих на ліберальній платформі, що є запорукою справедливості СЕП.

Ключові слова: глобалізація, міжнародні відносини, світовий економічний порядок, глобальне управління.

Онищенко В. Генезис мирового экономического порядка. Определено, что мировой экономический порядок (МЭП) - это система международных отношений между субъектами мировой экономики, которая структурирована легитимными формальными и неформальными правилами. Определено, что МЭП сформирован естественным путем в глобальном пространстве экономической и политической конкуренции. Исследовано, что цель, дерево иелей, структуру отношений в рамках МЭП определяют страны-лидеры через систему легитимных глобальных институтов, основанных на либеральной платформе, что есть залогом справедливости МЭП.

Ключевые слова: глобализация, международные отношения, мировой экономический порядок, глобальное управление.

Постановка проблеми. Світ динамічно трансформується, спостерігаються суттєві зрушення у світовій економіці й торгівлі, де основними акторами є США та Китай, протистояння яких змінює розклад сил на світовій політичній та економічній мапі. Не варто забувати й про менш важливі країни, які можуть спричинити масштабні трагедії. На тлі пандемії COVID-19 зростає напруга, так звані глобальні інститути на сьогодні не достатньо ефективні в іï регулюванні. Тож необхідно їх модернізувати з метою формування та утримання такого стану міжнародних відносин, зокрема й економічних, який би задовольняв принаймні їхніх суб'єктів і запобігав силовим конфліктам та економічним війнам. Важливо зрозуміти інваріанти та

(C) Онищенко В., 2020 
детермінанти механізму формування світового економічного порядку (СЕП) для визначення «больової точки» цього організму, впливаючи на які змінювати світ на краще.

Аналіз останніх досліджень і публікацій. Проблемою СЕП активно займаються провідні політики і економісти світу та України, як-от: автори Доповіді Римського Клубу-18 «A Finer Future: Creating an Economy in Service to Life» («Більш чудове майбутнє: створення економіки, яка слугує життю») А. Війкман, Ст. Уолліс і Дж. Фуллертон [1], Г. Аллісон [2], Г. Кісінджер [3], С. Хантінгтон [4], К. Шваб [5], О. Білорус [6], Д. Лук'яненко [7], Н. Рєзникова [8], В. Юрчишин [9] та інші. Проте наразі постали питання, які потребують модернізації СЕП на новій методологічній платформі, в основу якої варто покласти не лише економічний дискурс, але й аксіологічний контекст суспільного розвитку, тобто враховувати цінності, що керують світом і формують уяву людини та іiі спільнот про світ, сенс життя, зокрема й економічного, про справедливість та інші моральні імперативи. Адже, як зазначав Гегель, реальність зіткана $з$ наших уявлень. Необхідно створити концепцію, яка пов'язуватиме економіку як дескриптивну науку 3 нормативною сутністю людського життя. У цьому контексті заслуговують на увагу фундаментальні праці Дж. Акерлофа та Р. Шілера [10], С. Боулза [11], П. Бурдьє [12], А. Сена [13]. Серед вітчизняних науковців, передусім, цю проблему розглядають В. Базилевич і В. Ільїн [14], А. Мазаракі [15].

Мета статті - уточнити ціль, зміст та детермінанти генезису світового економічного порядку.

Матеріали та методи. Методичною основою дослідження стали праці вітчизняних і закордонних фахівців, використано загальнонаукові методи дослідження: історичний, логічний аналіз, синтез та абстракції.

Результати дослідження. Розглядаючи глобальний порядок як структуровану систему міжнародних відносин, варто визначити його мету.

Важливо з'ясувати, що глобалізація - це природний еволюційний просторово-часовий процес соціалізації людства, який не може відбуватися без узгодження інтересів людей на всіх рівнях суспільних структур. Глобалізація як процес не має мети, поготів моральних властивостей. Вона є атрибутом буття людства і має свій зміст та внутрішню логіку, тобто внутрішню доцільність, яка визначається виживанням людства як біологічного та соціального виду - життя заради життя. Це перманентний процес, сутність якого - «кінцева мета ніщо; рух до неї - все». Глобалізації притаманна самоорганізація, тобто її спонтанні процеси в своєму розвитку та взаємодії прокладають шлях до оптимальної траєкторії соціалізації людства. Результат глобалізації - соціальний простір, що є зв'язно-диференційованою структурою, елементами якої є суб'єкти зі своїми цілями та усвідомленою стратегією їхньої реалізації. Цей простір не може бути однорідним, 
оскільки всі його елементи мають свій габітус, тобто природну індивідуальність [16].

Будь-який соціальний простір структурується соціальними зв'язками між своїми елементами, а їхня щільність визначає ефективність соціальної взаємодії: максимальна щільність - сім'я, мінімальна планетарний рівень, тобто за зростання кількості залучених суб'єктів вона зменшується. Рівень глобалізації розкриває щільність та ефективність соціальних зв'язків світового простору. Отже, рівень глобалізації світового простору, його соціальна та економічна щільність визначають особливості генезису та ефективність світового порядку.

Життєдіяльність, на відміну від буття, формується людиною і має мету, оскільки вона та іiі соціальні спільноти є інтенціональними суб'єктами, які цілеспрямовано пізнають себе і світ для задоволення особистих та суспільних потреб. Безумовно, людина взаємодіє $з$ глобалізацією, намагаючись створити сприятливі умови для реалізації своїх конкретних цілей, що проявляється, наприклад, в інтеграційних утвореннях різного гатунку, створенні тимчасових «світових порядків», але людина не може змінити іiі еволюційну ходу та надати іiі внутрішній доцільності конкретного змісту.

Яка ж мета цієї взаємодії? Людство має одну для всіх іманентну аксіологічну мету (цінність, потреба) - жити. Життя само по собі має цінність, але щоб продовжувати свій рід і пристосовувати світ і себе для задоволення індивідуальних та соціалізованих потреб, необхідно жити у безпеці. Тому ця умова породжує низку системно ув'язаних між собою цілей. Перший рівень глобальної мети - запобігання голоду, військовим та екологічним катастрофам. Цей рівень домінантний і інваріантний, він об’єднує людство. Другий рівень - задоволення матеріальних, культурних і духовних потреб. Ці цілі конкретизуються суб'єктами, зважаючи на цінності, ресурси та здатність до їхнього відстоювання у взаємодії 3 іншими суб'єктами. Цілі потребують реалізації, а реалізація - стратегії як організованої діяльності. Якщо ми говоримо про множину цілей суб'єктів міжнародних відносин, що мають свої стратегії щодо їхньої реалізації у просторі обмежених ресурсів, то вони мають бути узгоджені, щоб зменшити вірогідність силових протистоянь. А для цього необхідна структуризація міжнародних відносин, що і називається світовим порядком.

Світовий економічний порядок (СЕП) - це система міжнародних відносин між суб'єктами світової політики та економіки, соціальної, культурної та іншими сферами, яка структурована певними формальними та неформальними правилами. Формальні правила визначаються міжнародним правом та його інститутами, а також іншими міжнародними організаціями (ООН, СОТ, ЮНЕСКО тощо), що регулюють відносини у різних сферах діяльності на основі формальних домовленостей між суб’єктами міжнародних відносин. 
Неформальні правила та інститути міжнародних відносин виникають завдяки особливостям цивілізаційного контексту тієї чи іншої країни. Це іiі характер, який визначається цінностями народу, його культурою та релігією, історією тощо. Так, на зміст міжнародних відносин між Україною та Росією впливає історичний контекст російського імперіалізму; мають свої історичні корні непрості відносини України 3 Польщею, Польщі 3 Німеччиною, Великої Британії 3 Ірландією тощо. У цьому контексті доречно навести думку А. Мегілла про те, що розходження між народами «...є в основному об'єктами інтелектуальної історії та історії ідей. За допомогою цих конструктів, які частково складаються із чітко сформульованих ідей, але більшою мірою з неясно сформульованих форм габітусу, які істотно різняться по кожній культурі, - виникає розходження людей від того загального, що надано їм природою й у природі» * [17].

Г. Кісінджер вважає, що для встановлення дійсного світового порядку його елементи, зберігаючи власні цінності, потребують другої культури, яка є глобальною, структурованою та правовою [3, с. 495]. Локальними прикладами симбіозу культур є США, Канада, Мексика. Проте виникає питання, чи можливо сформувати цю «другу культуру» у більшому масштабі? Мабуть, поки що ні. Цивілізаційний контекст людського розвитку має вирішальне значення для самоідентифікації націй та країн як основних суб'єктів міжнародних відносин. Саме він формує різноманітність глобального суспільства, що є запорукою його консенсусного розвитку в напрямі формування глобальної цивілізації майбутнього.

Міжнародний простір має силову природу, тож його системна структуризація повинна це враховувати. Кожен суб'єкт системи має не тільки свої інтереси, але й ресурси для їхньої реалізації (потенціал), а також силу впливу (реалізація потенціалу), ефективність якої визначається відношенням витрачених ресурсів, включаючи час, до умовної або фактичної цінності результату. Важливо оцінити ці характеристики для кожного суб'єкта і - головне - іхні співвідношення, аби зрозуміти, в якому напрямі може еволюціонувати міжнародний порядок, i «підштовхувати» його до бажаної траєкторії.

У формуванні міжнародного порядку є своя логіка: це інтереси суб 'єктів, характер їхнього конфлікту, який, своєю чергою, розкриває зміст процесу перерозподілу ресурсів (благ) між суб'єктами, а також особливостяли створення та функціонування міжнародних інститутів, що регулюють цей процес. Тож конфлікт інтересів, процес перерозподілу ресурсів і міжнародні (глобальні) інститути визначають топологію світового економічного простору.

У цьому контексті є різні моделі міжнародних відносин, зокрема й економічних: теорія гегемоністської стабільності (hegemonic stability

* Всі цитати з іншомовних джерел наводяться у перекладі автора статті. 
theory), теорія транснаціоналізації (transnational theory), теорія міжнародних режимів (regime theory). Зауважу, що досить популярним серед «лівих» та інших популістів став концепт соціального конструктивізму, сутність якого полягає в ідеї створення глобального уряду та побудови справедливої моделі міжнародних відносин, що є неможливим.

Світовий порядок формується не чиєюсь волею, а структурується у широкому розумінні силовими відносинами: цивілізаційними протистояннями, боротьбою за ресурси, за владу, насамкінець війнами. Тож «багатополярний світ», як і будь-яка його модель, не може формуватися за бажанням ООН чи якоїсь іншої організації, або країни, наприклад - Росії, яка весь час про це говорить. Він формується конкурентною боротьбою між країнами, що $\epsilon$ природним, і приймає, так би мовити, обличчя переможців. Згодом переможці будуть іншими і світовий порядок теж зміниться. Ф. Хайєк зазначає, що «...ми повинні нарешті зрозуміти, що сучасний соціальний порядок $\epsilon$ не результатом свідомого планування, а результатом виживання більш ефективних інститутів у процесі конкуренції» [18, с. 476].

Конкуренція створює лідерів, які першими засвоїли ефективні економічні, соціальні та політичні практики. Саме вони і є провідною силою, що формує світовий порядок. Як правило, лідерів небагато одна чи декілька країн. Безумовно, їхні дії будуть обмежуватися конкурентним тиском інших вагомих суб'єктів, певними домовленостями та міжнародним правом, тобто міжнародними інститутами, але тенденції світового розвитку задаватимуть вони. На сьогодні це США, Китай та ЄС. Щодо Росії, то це специфічний суб'єкт, який має недолугу економіку, однак значний військовий потенціал, завдяки якому створює проблеми, що дестабілізують. Росія - «еnfant terrible» світового масштабу. Стосовно інших центрів впливу, то це ООН та іiі структури, СОТ, МВФ, Світовий банк тощо.

Г. Кісінджер риторично заявляє, що по-справжньому глобального «світового порядку» ніколи не існувало і не існує. По суті, сьогодні реально є Вестфальська система, іiі створювали тільки європейські держави, вона відображає європейський погляд на світоустрій [3, с. 10]. Якщо Кісінджер мав на увазі «формальний світовий порядок», який може існувати лише за умови «глобального уряду», то його дійсно немає i не може бути. Існує тільки неформальний, важко прогнозований порядок. А тому природним завданням світової спільноти є зниження рівня його невизначеності шляхом інституалізації.

Г. Кісінджер також зазначає, що ми живемо в історичний період, для якого $є$ характерним майже відчайдушна гонитва за невловимим загальним розумінням концепції світового порядку [3, с. 6]. Але як вважає А. Мегілл, варто, принаймні, «...розуміти глобальну історію» [17], тобто соціокультурну генезу людства та його структурних складових, i знайти в ній інваріанти людського буття та діяльності, щоб був фундамент такого порядку. 
Стосовно Вестфальської системи, то їй поки що немає альтернативи, адже наріжним каменем iï фундаменту є держава та іï суверенітет. Ця система не заперечує різного роду інтеграційні об'єднання 3 делегуванням певних суверенних прав членів такого об'єднання спільним інститутам. Якщо говорити про якісь «світи»на кшталт «руського мира», «арабського халіфату» чи «ісламського світу», а може й «китайського», то ці об'єднання матимуть цивілізаційний, політичний та економічний зміст. Але їхня міжнародна правова суб'єктність залежатиме від рівня, змісту та форми інтеграції. Країни змушені будуть поступитися часткою свого суверенітету. В цьому випадку йдеться про так званий «парадокс Родріка», зміст якого полягає в оберненій залежності рівня класичної суверенності держав і рівня глобалізації. Наприклад, В. Юрчишин, посилаючись на Д. Родріка [19], вважає, що «...у довгостроковій перспективі взаємоузгоджене співіснування трьох процесів - глобалізації, демократії та національної держави - практично виключається. Тому серед найважливіших питань світоустрою, на які вже сьогодні потрібно знаходити відповіді, виокремлюється те, який тип глобальної стратегії домінуватиме - поглиблення співробітництва і формування інтеграційних альянсів чи посилення протекціонізму 3 активізацією торговельних і валютних війн» [9, с. 133]. Проте 3 цією тезою важко погодитися, адже це формальне розуміння «парадоксу Родріка».

По-перше, глобалізація не заперечує взаємоузгодженого існування 3 демократією та національною державою, оскільки вона не є примусовим процесом, а формує умови для тісної співпраці та глибшого взаєморозуміння між країнами, що $\epsilon$ запорукою створення ними різних добровільних локальних форматів глобалізації для інтеграції ресурсів заради досягнення власних цілей, трансформованих у спільні. По-друге, країни можуть формувати спільні наднаціональні інститути, яким добровільно передають частину свого суверенітету для демократичного прийняття рішень та розробки й ефективного втілення наднаціональних стратегій. Тобто виникає новий суб'єкт суверенності, однак країни його не втрачають. По-третє, якщо певну країну щось не влаштовує, то вона має право вийти з інтеграційної угоди демократичним способом, приклад - Brexit. I, nо-четверте, «глобальної стратегії» не існує, це, скоріше, «фігура мови». $Є$ певний СЕП, що визначає тренди та простір можливих стратегій поведінки кожному своєму суб'єкту. А вже на цьому просторі можливостей суб'єкти можуть домовитися про спільні дії, проте ця домовленість, зазвичай, має нестійкий консенсусний фундамент, який потребує постійного корегування відповідно до «забаганок» сторін.

Ми не знаємо, яким стане світ років через 25-30. Але можемо визначити тенденції його розвитку принаймні на найближчі 10 років. По-перше, світова економічна та політична система $є$ досить інерційною, й картина світу, яка в основному склалася у 2010 р., помінялася за 
десять років незначно, хіба що Китай посилився ще більше, Росія стала агресивнішою, США успішно розвиваються, Велика Британія вийшла з $\mathrm{CC}$, що не сильно вплинуло і не матиме впливу на Свропу. На економіку, безумовно, вплине COVID-19, але він не зрушить наявний СЕП. По-друге, основне суперництво США - Китай залишиться на невизначений час. Суперництво це має цивілізаційний характер i розв'язує питання: що є ефективнішим - «китайський імператор» чи «західний ліберал». Імперії віджили, тому переможе модернізований ліберальний вектор розвитку. Щодо Китаю, то з часом його державна система, яка існує 2500 років, має змінитися. Якою вона стане, важко сказати, але за формою та змістом буде віддзеркалювати багатовікову велику китайську цивілізацію. Процес буде непростим через багатонаціональний склад, різноманітність укладу, традицій та ментальності народів країни.

Щоб підтримувався будь-який порядок, необхідно за ним слідкувати. Ю. Харарі влучно зауважив, що світовий порядок зараз схожий на будинок, в якому всі живуть, але ніхто його не ремонтує [20]. Це певне перебільшення, але є глобальні проблеми та процеси, і вони потребують рішення (зміни клімату та екологія, невиправдана нерівність, військові конфлікти та інше), тобто певного глобального управління. Свою точку зору стосовно глобального управління автор виклав у відповідній статті [21]. У загальному плані це наявність визнаного всіма (принаймні здебільшого) країнами міжнародного права та інститутів, що втілюють у життя світової спільноти його норми та відповідають за їхнє дотримання. Саме право гарантує глобальну справедливість і суверенітет держав. Головне завдання - розробити таке право й норми його реалізації, які всіх задовольнятимуть. 3 огляду теорії це неможливо навіть на рівні країни (теорема Ерроу). Його можна тільки нав'язати або досягти нестійкого консенсусу, що потребує відповідного управлінського концепту, заснованого на «м'якому», узгодженому світовою елітою системному впливі на глобальні процеси через легітимні інститути. Жорсткий варіант глобального управління призведе до протистоянь та конфліктів. Тому парадигма глобального управління повинна грунтуватися на ліберальній основі, що $є$ запорукою ii справедливості. Переваги ліберального концепту повною мірою відчули бідні країни, громадяни яких масово мігрують до США та ЄС. Тож вважати, що лібералізм та його різновиди $є$ неефективними в управлінні міжнародними процесами, недоречно. До того ж ніхто іншого не пропонує. У. Черчилль зазначав: «демократія - найгірша форма правління, якщо не зважати на інші». Демократія та лібералізм побудовані на консенсусі інтересів, що гарантує справедливість і довіру наріжні моральні імперативи людства. Тож імперії ніколи не були справедливими.

Світова економічна спільнота здебільшого приділяє увагу соиіальним і моральним проблемам економічної діяльності та світового 
економічного порядку, ув'язуючи їх з проблемою економічного зростання. Проблеми моральності економічної діяльності мають давню історію, про це говорили Д. Юм, А. Сміт, Дж. Мілль, а нині це стало популярним наративом $[11 ; 22-24]$. Проте що таке моральна економіка незрозуміло. Моральною може бути економічна діяльність, тобто бізнес, оскільки він забезпечує робочі місця, прийнятну платню, максимізує прибуток і справно сплачує податки до бюджету. Все інше - сфера відповідальності суспільства, релігій, держави та іiі інститутів, які мають створити відповідні умови для відтворення суспільних потреб і розвитку громадян. «Кесарю - Кесареве, а Божіє Богу» [Матф. 22.21]. До речі, на Давосі-20 проблеми «моральності» економіки розглядали 3 позицій екології, сплати податків, офшорів, тобто у контексті економічної діяльності.

Питання онтології моральності науки, зокрема й економіки, якою має бути наука - дескриптивною чи нормативною. Позиція автора: наука $є$ дескриптивною. М. Алле 3 цього приводу писав: «Завдання економічної науки - вивчати те, що роблять люди для задоволення своїх потреб, без будь-якого попереднього судження про те, якими можуть бути ці потреби і яка їхня ієрархія» [25, с. 113]. Моральні та етичні категорії слугують основою політики. Саме політика як нормативна діяльність визначає мету економічного розвитку, а завданням економічної науки є розробка можливих траєкторій iї досягнення. Тобто формувати те, що ми називаємо економічною політикою, в основі якої знаходяться бажання суспільства, що віддзеркалюють політики. Тож щодо стану економіки держави, то справа не в економістах, а у політиках, які формують нереальні цілі.

Моральні проблеми глобального світу та його порядку, безумовно, існують. Г. Кісінджер зауважує, що будь-який світовий порядок, аби бути життєздатним, має сприйматися як справедливий не тільки лідерами, але й пересічними громадянами [3, с. 480]. Свою точку зору щодо справедливості міжнародних економічних відносин автор виклав у однойменній статті [26]. У ній обгрунтовується, що справедливими відносини можливо вважати за умови, що їхні суб'єкти не мають аргументованих заперечень проти наявних між ними домовленостей, і вони є економічно рівноважними. Справедливість - категорія моральна та суб'єктивна, тож іiі економічне трактування можливе лише у термінах концепції утилітаризму.

У кожної нації, етносу та людини $є$ свої уявлення про справедливість, однак всі мають приблизно однакове розуміння основних моральних засад існування та розвитку їхньої спільноти. Отже, ми вважаємо моральний імператив атрибутом людського буття. У будьякій країні громадяни здебільшого дотримуються однакових моральних стандартів (неформальні інститути), що визначають законодавчі норми держави (формальні інститути). Але існують розбіжності у механізмах забезпечення цих стандартів (суспільні фінанси та ресурси, 
механізм їхнього розподілу, право та судочинство), тобто у формах, методах забезпечення справедливості розподілу матеріальних і соціальних благ. Європейський підхід - це ринкова справедливість. ісламський, індуїстський, буддистський та інші світи мають своє розуміння справедливості економічних відносин. Варто порівняти, яке відношення українця, американця чи шведа до сплати податків, і які покарання вони несуть за порушення закону. Тому справедливий глобальний економічний порядок - fata morgana.

Дещо про «несправедливість» економічного добробуту країн світу. Наприклад, В. Лагутін зазначає: «У світовій економіці виявляються суперечливі процеси як зближення, так й розходження напрямів розвитку (дивергенції) національних економік. Периферійні країни у XXI ст. ні у короткостроковій, ні у середньостроковій перспективах не перетворяться на розвинені» [27, с. 14]. За розрахунками ЮНКТАД підтверджується, що у «периферійних», тобто бідних країн шанси стати розвинутими мізерні (таблиия). Але вони можуть стати середньо розвинутими, в них є шанси і деякі ними скористалися.

Таблиия

\section{Вірогідність переходу країн у вищі групи за рівнем ВВП на душу населення}

\begin{tabular}{|c|c|c|c|c|c|c|c|c|}
\hline & \multicolumn{5}{|c|}{ Коефіцієнт вірогідності переходу в іншу групу на кінець періоду } \\
\cline { 3 - 10 } \\
\cline { 2 - 10 } \\
\cline { 2 - 9 }
\end{tabular}

${ }_{* *}^{*}$ розрахунки ЮНКТАД [27, с. 42].

розрахунки автора

За оцінками ЮНКТАД, шанси на наявне зростання доходів країн, що розвиваються, на кінець 2010 р. у ході глобалізації знизилися в декілька разів проти 1950-1980 рр. (див. таблицюю). Зазначено, що «...у ході глобалізації можливостей для зближення груп країн, що розвиваються, з різними доходами стало менше проти 1950-1980 pp. Вірогідність переходу будь-якої країни з групи з середнім доходом до групи з високим скоротилася з 18 \% у 1950-1980 рр. до 8 \% у 19812010 рр. Знизилися шанси переходу з групи з низьким доходом до групи з середнім - с 15 до 7 \%» [28, с. 42].

Проте у 2011-2020 рр. картина дещо змінилася - вірогідність переходу країни 3 групи середнього доходу до групи 3 високим - 
підвищилась 38 \% до $18 \%$, а 3 групи низького доходу до середнього $37 \%$ до $21 \%$. Розглянемо це 3 посиланням на методичний підхід фахівців ЮНКТАД, які розглядають три групи країн за рівнем ВВП (ПКС) на душу населення: 3 низьким рівнем доходу - менше ніж $15 \%$ від рівня США; з середнім рівнем - 15-50 \%; з високим рівнем - понад 50 \% від рівня США. Якщо орієнтуватися на цей критерій групування країн, то результати аналізу свідчать, що у 2010 р. розвинутих країн було 40, середнього розвитку - 57, бідних - 94; у 2019 р. відповідно 50, 67 та 74 країни. Тож, за дев’ять років розвинутих країн зросло на десять, також на десять збільшилось країн 3 середнім розвитком i, відповідно, на 20 стало менше бідних країн. Такий показник відповідає загальній тенденції - світ багатіє. Феномен 2011-2019 рр. можна пояснити тим, що після кризи 2008 р. відбувався динамічний розвиток світової економіки, особливо країн, що розвиваються, а також «нових європейців». Наприклад, до розвинутих країн увійшли Польща, Португалія, Литва, Угорщина, Естонія, Хорватія; до країн середнього розвитку перейшли Україна, Вірменія, Грузія, Азербайджан, Йорданія, Алжир та ще 14 країн. Тому висновок про зменшення шансів за умов глобалізації перейти у багатшу групу не відповідає реаліям. Та й до чого тут глобалізація, начебто, якщо Судан не був би «глобалізованим», то країна була би багатшою. Безумовно, нерівність країн за доходами була, є і буде, і вона має тенденцію до збільшення, але за вищої бази щодо порівняння. До того ж, в цьому випадку висновок залежить від того, як групувати країни та як визначати коефіцієнт перерахунку доходів за порівняльною купівельною спроможністю для кожної країни.

Надалі технічна революція 4.0 може посилити дивергенцію країн, особливо відстануть найменш розвинуті, а також країни з середнім доходом та «низьким високим» (від 51 до 75 \% ВВП США), вони не матимуть достатнього власного потенціалу до інноваційного розвитку. США, Китай, Японія, Німеччина, Франція та Велика Британія відірвуться від основної групи та фактично встановлять «технологічну диктатуру». Тож переможцями будуть країни, які мають розвинутіший і капіталізований суспільний інтелект, у якому провідне місце займає людський капітал. Саме за нього й ведеться запекла боротьба. Лідерами будуть країни, які створять умови для його ефективного відтворення, залучаючи не тільки власні ресурси, але й ресурси інших країн. А тому проблема «відтоку мозків» стає надзвичайно актуальною, особливо для таких країн, як Україна, які за низького рівня економічного розвитку мають достатньо високий рівень освіти молоді.

До речі, окрім технологічного відставання, ці країни позбудуться мільйонів робочих місць, оскільки штучний інтелект і роботизація нівелюють привабливість їхніх трудових ресурсів. Безумовно, будуть створюватися нові робочі місця, але здебільшого в розвинутих країнах. Скоротиться кількість глобальних корпорацій, що не тільки 
надавали роботу, але й залучали країни до нових технологій і знань, сприяли зростанню добробуту їхнього населення.

Сьогодні світ має двох амбіційних економічних лідерів - США та Китай. Стосовно суперництва Китаю та США для майбутнього світового порядку воно принесе багато нового, головне, аби воно не переросло в силове протистояння. Для цього $є$ певні застереження, про які свідчить історія виникнення двох світових війн. Це так звана пастка Фукідіда (Фукідід - давньогрецький історик, відомий 3 «Історії Пелопоннеської війни»), термін ввів до політичного сленгу Гр. Аллісон. Приводом до війни може стати захист державою-лідером свого положення від зазіхань суперника чи суперників [2, с. 9]. Така ситуація виникла у відносинах між США та Китаєм. Водночас автор не стверджує, що це обов'язково призведе до війни: «Пастка Фукідіда не фатальна й не дає підстав для песимістичних поглядів. Вона спонукає нас абстрагуватися від газетних заголовків і політичної риторики й визнати ті тектонічні процеси, які Пекіну й Вашингтону належить приборкати, аби вибудувати мирні відносини» [2, с. 10]. Як казав Фукідід, тільки взаємний страх робить союз і мир надійним. Вірогідність війни між США та Китаєм мінімальна, проте Гр. Аллісон, посилаючись на історію війни сторічної давнини (першої світової), застерігає, що вона «...змушує знову і знову вражатися людською дурістю» [2, с. 10]. Історикам досі не зовсім зрозуміло, чому ця війна почалася.

Окрім силового $є$ економічне протистояння у різних формах, зокрема «торговельна війна». Це природний процес конкуренції. Китай за темпами розвитку випереджає всіх, а не тільки США. Виникає питання, за який час Китай наздожене США в економічному розвитку (за валовим обсягом ВВП і за ВВП (ПКС) на душу населення)?

За обсягом ВВП: стартові умови (2019 р.) - ВВП США = 21,5, Китаю $=13,6$ трлн дол. США [29]. Розглянемо три варіанти:

- за середньорічних темпів приросту ВВП США на рівні $3 \%$ і $6 \%$ - Китаю, вірогідність зрівняння зі США - через 15 років;

- США - $2 \%$, Китай - $4 \%$ річного приросту, вірогідність зрівняння - за 20 років;

- за темпами приросту відповідно $1 \%$ та $3 \%$; Китай зрівняється зі США через 25 років.

Навіть якщо США не розвиватимуться, а у Китаю темпи становитимуть $4 \%$ на рік, то вони зрівняються через 12 років. Зауважимо, що за ВВП у ПКС Китай значно обійшов США (27,3 проти 21,5 трлн дол. США) [29]. Але ВВП у ПКС агреговано характеризує внутрішній ринок країни та порівняльну 3 іншими країнами купівельну спроможність населення. У сфері світової економіки міжнародні порівняння економічних потенціалів країн мають здійснюватися у валюті міжнародних розрахунків, тобто у доларах США. 
Дещо інша ситуація щодо рівня життя. ВВП (ПКС) на душу населення: стартові умови (2019 р.) - ВВП США = 62,6; ВВП Китаю = 18,1 тис. дол. США в рік; кількість населення змінюється однаково. За середньорічних темпів зростання маємо такі результати: 45 років, 65, 60 та 32 роки. Проте може все статися. Зауважимо, що китайська економіка наближається до «перегріву». До того ж Китай не має перспектив стосовно зрівняння зі США за інноваційністю економіки. На сьогодні розвиток науки Китаю відстає від США років на 20.

Великі надії Китай покладає на проєкт «Один пояс, один шлях». Цьому проєкту США та їхні союзники поки не можуть дати аналогічної відповіді. Скоріше за все, для розподілу світового впливу між США та Піднебесною, Америці варто увійти у цей проєкт, якщо не економічно, то політично, щоб розуміти, як балансувати світовий порядок.

Стосовно геополітичних та економічних намірів Росії - вона страждає «веймарським синдромом» (реваншистський настрій колишньої імперії у намаганні відродити свою могутність). Основою геополітики Росії є імперіалізм, мілітаризм та реваншизм. Росія на сьогодні проводить таку політику, що ризикує опинитися у пастці «імперської перенапруги». У своїх домаганнях Росія сподівається на союз із Китаєм, який забезпечить КНР економічну міцність, а РФ - військову, тобто «силовий дах» економічної гегемонії Китаю. Проте Росія в цьому союзі може бути лише на других ролях.

Геополітичне та геоекономічне завдання України - вирватися 3 братніх лещат Росії та інтегруватися до НАТО і СС, активно розвивати стосунки з державами, які можуть допомогти Україні у ії економічних та політичних прагненнях.

Україна, на жаль $\epsilon$, країною з малою економікою. Розрахунки, за статистикою Світового банку та ЮНКТАД, свідчать, що на 01.01.2020 p. частка України у світовому ВВП за номіналом у дол. США - 0,15 \%; у світовому експорті товарів та послуг - 0,25 \%; у світовому ринку прямих інвестицій - 0,18 \%; Україна займає $117-е$ місце у світі за ВВП (ППС) на душу населення - 9,3 тис. дол. США на рік за середньосвітового - 16,8 [29]. Розмови про можливості інноваційного розвитку України, про забезпечення високих темпів економічного зростання на новій технологічній основі, сподівання, що ми доженемо й випередимо когось у Європі (наприклад, Молдову чи Грузію) безпідставні не вистачає людського капіталу.

Щодо розподілу країн за рівнем душового доходу ВВП та рівнем їхньої інноваційності спостерігаємо пряму залежність між ними. За оцінкою автора, до рівня 30-40 тис. дол. США ця функція майже не зростає, і тільки після досягнення цього рівня починається іiі достатньо стрімка динаміка. Але Україна навіть за середньорічних темпів приросту в 5 \% (гіпотетично) їі досягне в кращому разі за 20-25 років.

Україна, на жаль, не використовує навіть ті ресурси, які має. Різноманітність і запаси ії мінеральних ресурсів оцінюються експертами 
у 8 балів за 10-бальною міжнародною шкалою [30]. Україна за запасами основних видів корисних копалин посідає одне 3 перших місць у Свропі, є також 42,4 млн га найліпшої й найбільшої площі у Європі землі сільськогосподарського призначення [31], є поки що людський ресурс, але маємо неефективну владу - за індексом слабкості держави (The Fragile States Index 2019; чим більший рейтинг, тим слабша держава) Україна займає серед 178 країн 91-е місце, фактично у середині світового рейтингу [32].

Країні потрібна ефективна влада за формулою «правопорядок демократія - розвиток». Необхідно сповідувати та активно просувати національні інтереси, потрібно поєднувати інтернаціоналізм та націоналізм. Ю. Харарі переконаний, що націоналізм - це любов до своїх співгромадян; що хороший націоналіст XXI століття - це глобаліст, оскільки глобалізм не заперечує унікальність кожного народу, а лише регулює відносини між ними [20].

Проблеми України породжені внутрішніми негараздами, радянським та російськоімперським минулим. Перед нами ще стоїть проблема ідентичності, не московської, а європейської. Для іiі рішення необхідно виконати, як відзначає С. Хантінгтон, три умови: по-перше, еліта країни повинна з ентузіазмом сприймати і всіляко підтримувати це прагнення; nо-друге, суспільство повинно мати чітку позицію щодо переорієнтації ідентичності; по-третє, цивілізація, що приймає (Захід), повинна принаймні бажати прийняти таку країну [4, с. 483]. Жодна умова на сьогодні не втілена, і в цьому провина національної еліти. Україна для неї - бізнес-проєкт особистого збагачення і вивозу капіталу у кращі країни, а наша байдужність і поступливість, віра у популістичні гасла $\epsilon$ однією з причин нашої бідності. Бідна людина фокусується на «кусні хліба», тобто на сьогоднішніх проблемах і цілях, не планує «завтра», а тому живе без майбутнього.

Висновки. Визначено, що світовий економічний порядок (СЕП) це система міжнародних відносин між суб'єктами світової економіки, яка структурована легітимними формальними й неформальними правилами та інститутами.

Досліджено, що:

- СЕП формується природним шляхом у глобальному просторі економічної та політичної конкуренції;

- СЕП легітимізується міжнародним правом, міжнародними домовленостями як у полі міжнародного права, так і поза ним;

- мету, дерево цілей, структуру відносин в рамках СЕП визначають країни-лідери через систему легітимних глобальних інститутів, заснованих на ліберальній платформі, що є запорукою справедливості СЕП;

- формується біполярний СЕП, оскільки суперництво США та Китаю $є$ і ще довгий час буде глобальним чинником;

- жодна країна з рівнем душового доходу у ППС до 30 \% від рівня США, зокрема й Україна, не зможуть перейти до групи розвинутих через п’ятдесят і більше років, а тому вони будуть аутсайдерами СЕП. 
Сьогодні перед світовою спільнотою стоїть надзвичайний виклик - COVID-19. Безумовно, пандемію подолають, проте наслідки для світової економіки будуть вельми серйозними і відчутними ще довго. Ця біда потребує єднатися людській спільноті в боротьбі 3 загрозами планетарного масштабу та об'єднати зусилля всіх країн для їхньої нейтралізації. Тож необхідно створити ефективний інституційний каркас світового порядку, який би віддзеркалював різноманіття інтересів та устремлінь націй і слугував процвітанню людства.

\section{СПИСОК ВИКОРИСТАНИХ ДЖЕРЕ}

1. Доклад Римского Клуба - 18. Более прекрасное будущее: создание экономики, служащей жизни. (A Finer Future: Creating an Economy in Service to Life). URL: https://www.obozrevatel.com/society/bolee-prekrasnoebuduschee-i-vosstanovitelnaya-ekonomika-analiz-doklada-rimskogo-kluba.htm.

2. Аллисон Гр. Обречены воевать (пер. с англ. В. Желнинова). Москва: АCT. 2019. $416 \mathrm{c}$.

3. Киссинджер Г. Мировой порядок. Москва: АСТ. 2015. 512 с.

4. Хантингтон С. Столкновение цивилизаций. Москва: АСТ. 2016. 640 с.

5. Шваб К. Четвертая промышленная революция. Москва: Эксмо. 2016. 138 с.

6. Білорус О. Г. Економічна глобалістика. Світ-система глобалізму: монографія. Київ: Університет Україна. 2016. 533 с.

7. Глобальное экономическое развитие: тенденции, ассиметрия, регулирование: монография; под науч. ред. Д. Лукяненко, А. Поручника, В. Колесова. Киев: КНЭУ. 2013. 466 с.

8. Резнікова Н. Економічна незалежність країн в умовах глобальних трансформацій. Київ: Агромедіагруп. 2018. 460 с.

9. Юрчишин В. Чинники і складові структурних змін у світовій економічній системі і наслідки для України. Глобальні тенденції $i$ перспективи: світова економіка та Украӥна. Київ: Заповіт, 2018. 202 с.

10. Акерлоф Дж., Шиллер P. Spiritus Animalis: или Как человеческая психология управляет экономикой и почему это важно для мирового капитализма. Москва: Юнайтед Пресс, 2010. 273 с.

11. Боулз С. Моральная экономика: почему хорошие стимулы не заменяют хороших граждан (пер. с англ.). Москва: Институт Гайдара. 2017. 336 с.

12. Бурдье П. Социология социального пространства (пер. с фр. Н. Шматко. Санкт-Петербург: Алейгейм, 2005. 288.

13. Сен А. Идея справедливости / Амартия Сен (пер. с англ.). Москва: Институт Гайдара; Фонд Либеральная Миссия, 2016. 520 с.

14. Базилевич В. Д., Ильин В. В. Метафизика экономики. Изд. 2-е, доработанное. Киев: Знання; Москва: Рыбари, 2010. 925 с.

15. Мазаракі А. А. Торгівля: історія, цивілізація, мораль. Київ: Книга. 2010. $624 \mathrm{c}$.

16. Бурдье П. Габитус. URL: http://bourdieu.name/content/gabitus-enciklopedijasociologii.

17. Мегилл А.О глобальной истории идей. URL: http://roii.ru/dialogue/ 42/roii-dialo 
18. Хайек Ф. Право, законодательство и свобода: Современное понимание либеральных принципов справедливости и политики (пер. с англ. Б. Пинскер, А. Кустарев под ред. А. Куряева). Москва: ИРИСЭН. 2006. $644 \mathrm{c}$

19. Родрик Д. Парадокс глобализации: демократия и будущее мировой экономики (пер. с англ. Н. Эндельмана; под науч. ред. А. Смирнова). Москва: Институт Гайдара. 2014. 576 с.

20. Харарі Ю. Н. Виступ на Всесвітньому економічному форумі в Давосі, 2020. URL: https://nv.ua/opinion/recommends/budushchee-mira-yuval-noyharari-o-tom-chto-zhdet-chelovechestvo-v-21-veke-poslednie-novosti50066647.html?fbclid=IwAR34G9WmtWMB.

21. Онищенко В. Глобальне управління у контексті міжнародної політекономії. Вісник КНТЕУ. 2018. №2. С. 121-133.

22. Стиглиц Д., Сен А., Фитусси Ж.-П. Неверно оценивая нашу жизнь: Почему ВВП не имеет смысла? Москва: Институт Гайдара. 2015. 216 с.

23. Седлак Т. Економіка добра і зла. Львів: Старий Львів. 2017. 520 с.

24. Сен А. Об этике в в экономике. Москва: Наука. 1996. 162 с.

25. Алле М. Экономика как наука (пер. с франц. И.А. Егорова). Москва: Наука для общества, РГГУ. 1995. 168 с.

26. Онищенко В. Справедливість у міжнародних економічних відносинах. Зовнішня торгівля: економіка, фінанси, право. 2019. № 2. C. 17-33.

27. Лагутін В. Цивілізаційні та інституційні фактори глобальних економічних трансформацій XXI ст. Зовнішня торгівля: економіка, фінанси, право. 2019. № 2. С. 5-19.

28. Доклад о торговле и развитии-2016. ЮНКТАД, ООН, Нью-Йорк, Женева, 2016. 255 с.

29. Статистика Всесвітнього Банку. URL: https://nonews.co/directory/lists/ countries/gdp-per-capita-ppp

30. Мінеральні ресурси України. URL: http://minerals-ua.info.

31. Земельний довідник України. URL: https://agropolit.com/spetsproekty/ 705-zemelniy-dovidnik-ukrayini--baza-danih-pro-zemelniy-fond-krayini.

32. Рейтинг країн світу за рівнем слабкості держави. URL: https://gtmarket.ru/ratings/failed-states-index/info

Стаття надійшла до редакиіï 04.04.2020.

Onyshchenko V. Genesis of the World Economic Order.

Background. The existing World Economic Order (WEO) has become obsolete and needs modernization in order to form and maintain an equilibrium state of international economic relations that would prevent military and economic conflicts. Therefore, it is necessary to understand the genesis of the world order and the determinants of its development.

Analysis of recent research and publications. Leading politicians and economists of the world and Ukraine are actively engaged in the WEO problem: But a new outline of international problems has emerged, which requires the modernization of the existing WEO on a methodological platform based on taking into account the interests of all its subjects through the lens of global community values and the imperative of global justice. 
The aim of the article is to clarify the goal, content and determinants of the genesis of the WEO.

Results. It is determined that the WEO is a system of international relations, which is structured by legitimate formal and informal rules. It is argued that: 1) the WEO is naturally formed in a global space of economic and political competition; 2) WEO is legitimized by international law, international agreements both in and outside the field of international law; 3) the purpose, system of goals, structure of relations within the framework of the WEO are determined by the leading countries through a system of legitimate global institutions based on a liberal platform, which is the key to the justice of the WEO; 4) economic and political rivalry between the USA and China determines and will determine the architecture and content of the WEO for a long time. It proves that no countries with low and medium levels of economic development, including Ukraine, will be able to reach the developed group in the next fifty years or more, and therefore they will be long-term outsiders of the WEO.

Conclusion. The bipolar WEO is being formed, as the rivalry between the USA and China is and will be a global fact for a long time.

Keywords: globalization, international relations, world economic order, global governance.

\section{REFERENCES}

1. Doklad Rimskogo Kluba - 18. Bolee prekrasnoe budushee: sozdanie ekonomiki, sluzhashej zhizni [The Report of The Club of Rome -18. More beautiful future: the establishment of an economy serving life] (A Finer Future: Creating an Economy in Service to Life). Retrieved from https:/www.obozrevatel.com/society/bolee-prekrasnoe-buduschee-i-vosstanovitelnaya-ekonomika-analiz-doklada-rimskogo-kluba.htm [in Russian].

2. Allison, Gr. (2019). Obrecheny voevat / Greham Allison; per. s angl. V. Zhelninova. [Doomed to fight (translated from English by V. Zhelninov)]. Moskva: AST [in Russian].

3. Kissindzher, G. (2015). Mirovoj poryadok. [World order]. Moskva: AST [in Russian].

4. Hantington, S. (2016). Stolknovenie civilizacij. [The clash of civilizations]. Moskva: AST [in Russian].

5. Shvab, K. (2016). Chetvertaya promyshlennaya revolyuciya. [The fourth industrial revolution]. Moskva: Eksmo [in Russian].

6. Bilorus, O. G. (2016). Ekonomichna globalistika. Svit-sistema globalizmu [Economic globalistics. The world-system of globalism]. Kyiv: Un-t Ukrayina [in Ukrainian].

7. Lukyanenko, D., Poruchnik, A., \& Kolesov, V. (2013). Globalnoe ekonomicheskoe razvitie: tendencii, assimetriya, regulirovanie. [Global economic development: trends, asymmetry, regulation]. Kyiv: KNEU [in Ukrainian].

8. Reznikova, N. (2018). Ekonomichna nezalezhnist krayin v umovah globalnih transformacij [Economic independence of countries in the context of global transformations]. Kyiv: Agromediagrup [in Ukrainian].

9. Yurchishin, V. (2018). Chinniki i skladovi strukturnih zmin u svitovij ekonomichnij sistemi i naslidki dlya Ukrayini [Chynnyky i skladovi 
strukturnyh zmin u svitovij ekonomichnij systemi i naslidky dlja Ukrai'ny]. Globalni tendenciyi i perspektivi: svitova ekonomika ta Ukrayina - Global trends and prospects: the world economy and Ukraine. Kyiv: Zapovit [in Ukrainian].

10. Akerlof, Dzh., \& Shiller, R. (2010). Spiritus Animalis: ili Kak chelovecheskaya psihologiya upravlyaet ekonomikoj i pochemu eto vazhno dlya mirovogo kapitalizma. [Spiritus Animalis: or How does human psychology manage the economy and why is it important for world capitalism]. Moscow: Yunajted Press [in Russian].

11. Boulz, S. (2017). Moralnaya ekonomika: pochemu horoshie stimuly ne zamenyayut horoshih grazhdan/Samuel Boulz; per. s angl. [Moral economics: why good incentives do not replace good citizens (translated from English)]. Moscow: Gaidar Institute [in Russian].

12. Burde, P. (2005). Sociologiya socialnogo prostranstva. Per. s fr. N. Shmatko. [Sociology of social space (translated from French by N. Shmatko)]. St. Petersburg: Alejgejm [in Russian].

13. Sen, A. (2016). Ideya spravedlivosti (per. s angl). [The idea of justice (translated from English)]. Moscow: Gaidar Institute; Liberal Mission Foundation [in Russian].

14. Bazilevich, V. D., Ilin, V. V. (2010). Metafizika ekonomiki. Izd. 2-e, dorabotannoe [Metaphysics of Economics. Ed. 2nd, modified]. Kyiv: Knowledge. Moscow: Rybari [in Russian].

15. Mazaraki, A. A. (2010). Torgivlya: istoriya, civilizaciya, moral [Trade: history, civilization, morality]. Kyiv: Kniga [in Ukrainian].

16. Burde, P. Gabitus Retrieved from http://bourdieu.name/content/gabitusenciklopedija-sociologii [in English].

17. Megill, A. O globalnoj istorii idej [About the global history of ideas] Retrieved from http://roii.ru/dialogue/42/roii-dialo [in Russian].

18. Hajek, F. (2006). Pravo, zakonodatelstvo i svoboda: Sovremennoe ponimanie liberalnyh principov spravedlivosti i politiki (per. s angl. B. Pinskera i A. Kustareva pod red. A. Kuryaeva) [Law, Legislation and Freedom: A modern understanding of the liberal principles of justice and politics (translated from English by B. Pinsker, A. Kustarev under the editorship of A. Kuryaev)]. Moscow: IRISEN [in Russian].

19. Rodrik, D. (2014). Paradoks globalizacii: demokratiya i budushee mirovoj ekonomiki / per. s angl. N. Endelmana; pod nauch. red. A. Smirnova [The paradox of globalization: democracy and the future of the world economy (translated from English by N. Endelman; under scientific edition of A. Smirnov)]. Moscow: Gaidar Institute [in Russian].

20. Harari, Yu. N. (2020). Vistup na Vsesvitnomu ekonomichnomu forumi $\mathrm{v}$ Davosi, [Speech at the World Economic Forum in Davos] Retrieved from https://nv.ua/opinion/recommends/budushchee-mira-yuval-noy-harari-o-tomchto-zhdet-chelovechestvo-v-21-veke-poslednie-novosti-50066647.html? fbclid=IwAR34G9WmtWMB [in Ukrainian].

21. Onishenko, V. (2018). Globalne upravlinnya u konteksti mizhnarodnoyi politekonomiyi [Global governance in the context of international political economy]. Visnik KNTEU - Herald of KNUTE, 2, 121-133 [in Ukrainian]. 
22. Stiglic, D., Sen, A., \& Fitussi, Zh.-P. (2015). Neverno ocenivaya nashu zhizn: Pochemu VVP ne imeet smysla? [Misjudging our life: Why does GDP make no sense?] Moscow: Gaidar Institute [in Russian].

23. Sedlak, T. (2017). Ekonomika dobra i zla. [The economy of good and evil]. Lviv: Starij Lviv [in Ukrainian].

24. Sen, A. (1996). Ob etike v v ekonomike [Ob jetike v jekonomike]. Moscow: The science. [in Russian].

25. Alle, M. (1995). Ekonomika kak nauka (per. s franc. I. A. Egorova [Economics as a science (translated from French by I. A. Egorov). Moscow: Science for society, [in Russian].

26. Onishenko, V. (2019). Spravedlivist u mizhnarodnih ekonomichnih vidnosinah [Justice in international economic relations]. Zovnishnya torgivlya: ekonomika, finansi, pravo - Foreign trade: economics, finance, law, 2, 17-33 [in Ukrainian].

27. Lagutin, V. (2019). Civilizacijni ta institucijni faktori globalnih ekonomichnih transformacij $\mathrm{HH} 1$ st. [Civilizational and institutional factors of global economic transformations of the 21 st century.]. Zovnishnya torgivlya: ekonomika, finansi, pravo - Foreign trade: economics, finance, law, 2, 5-19 [in Ukrainian].

28. Doklad o torgovle i razvitii [Trade and Development Report] (2016). UNCTAD, OON, New York, Geneva [in English].

29. Statistika Vsesvitnogo Banku [World Bank statistics], Retrieved from https://nonews.co/directory/lists/countries/gdp-per-capita-ppp [in Ukrainian].

30. Mineralni resursi Ukrayini [Mineral resources of Ukraine]. Retrieved from $\mathrm{http}: / /$ minerals-ua.info [in Ukrainian].

31. Zemelnij dovidnik Ukrayini [Land directory of Ukraine]. Retrieved from https://agropolit.com/spetsproekty/705-zemelniy-dovidnik-ukrayini--baza-danihpro-zemelniy-fond-krayini [in Ukrainian].

32. Rejting krayin svitu za rivnem slabkosti derzhavi [Rating of the countries of the world on the level of weakness of the state]. Retrieved from https://gtmarket.ru/ratings/failed-states-index/info [in Russian]. 